ROCZNIKI TEOLOGICZNE

Tom LXVII, zeszyt $10-2020$

DOI: http://dx.doi.org/10.18290/rt206710-10

\author{
LILIA RUDENKO \\ SVITLANA FEDORENKO
}

MYROSLAV FEDORENKO

\title{
FAMILY AS A DETERMINANT OF AGGRESIVE BEHAVIOR IN CHILDREN WITH INTELLECTUAL DISORDERS
}

\begin{abstract}
The article talks about the causes of aggressive behavior in children with intellectual disabilities of different age. It has been noted that behavioral disorders in children with intellectual disabilities occur in $25 \%-84 \%$ of cases, and the development of both positive and negative traits depends directly on family upbringing and education in the family. The study of the social situation of development of children and adolescents with intellectual disabilities confirmed the presence of predominantly negative characteristics of the social, cultural, educational and professional status of families in which children with intellectual disabilities are raised, which can be a source of influence that contradicts social norms. Unfavorable conditions in families of children with intellectual disabilities, lack of behavior, disability of proper behavior from parents, demonstration of aggressive behavior in the family and ensuring its support also cause aggressive tendencies in the behavior of this category of children.

It has been found that unfavorable family situation, conflicting in children with intellectual disabilities increases with age, reaching the highest level before adolescence.

It is proved that negative perception of a child with intellectual disturbance of a family situation, lack of emotional connections between family members, feeling of rejection and rejection of a child by adult family members causes not only manifestations of aggression, but also formation of aggressive behaviors.
\end{abstract}

Key words: aggressive behavior; family; family situation; children with intellectual disabilities; behavioral factors.

LiLIA RUdENKo - Doctor of Psychology, Professor, Head of the Department of Special Psychology and Medicine, Dragomanov National Pedagogical University; address for correspondence: Ukraine, Kyiv, 8/14 Turgenevska str., 01053; e-mail: lilianic1962@gmail.com.

Svitlana FedorenKo - Doctor of Pedagogical Sciences, Professor, Head of Department of Speech Therapy and Psychology, Dragomanov National Pedagogical University, address for correspondence: Ukraine, Kyiv, 8/14 Turgenevska str., 01053; e-mail: fedorenkosvit@gmail.com.

Myroslav FedorenKo - Lecturer, Department of Special Psychology and Medicine, Dragomanov National Pedagogical University; address for correspondence: Ukraine, Kyiv, 8/14 Turgenevska str., 01053; e-mail: mf16@ukr.net. 


\section{STUDY TOPICALITY}

The problem of deviant behavior of children and adolescents with intellectual disabilities is extremely important in modern special psychology. ${ }^{1}$ Behavioral statistics in children and adolescents are very controversial. According to some authors, behavior disorders occur in $25-30 \%$ of children with intellectual disabilities, and according to others - in $84 \%$. Birth cerebral abnormalities, total mental underdevelopment not only distort the temper of the child, but also deform the formation of character and personality as a whole. The rate of formation of certail psychological aspects is disturbed, which in itself already affects the formation of socially active behavior, changes the quality of reactions to social influence, etc. ${ }^{2}$

In similar behavior disorders in children with normotypic development of their genesis in children with intellectual disabilities, at the same time with similarities, their features are defined as external (family, school, relations with peers) and internal (reduction of intelligence as a tool the balance of personality with the environment, the absence or weakness of the struggle of motives, inertia of mental processes, mental disorders and its neurodynamics) factors. ${ }^{3}$

The family is one of the social institutions. Family life, relationships between family members have a significant impact on the child's psychosocial development. ${ }^{4}$ Parents become the primary source for imitation, an example of establishing harmonious relationships that provide security and emotional well-being (M. Bardyshevskaya, R. Ovcharov, A. Spivakovskaya, N. Fedotova, N. Shevchenko, C. Rogers). Interpersonal family relationships are different from all other types of interpersonal relationships with high emotional significance for both the child and his or her relatives (A. Varga, O. Zaporozhets, M. Lysina, O. Nasonov, A. Spivakovskaya, V. Stolin, M. Aworth, J. Bowlby, E. Erikson, A. Freud, D. Winnicott), constant dynamics and development of each member individually and their interaction and interaction in general (O. Bondarchuk, A. Varga, D. Kornienko, J. Belsky, M. Bowen,

\footnotetext{
${ }^{1}$ G.K. PopPE, "Narushenija povedenija u oligofrenov," in: Biologicheskie i social'nye faktory narushenij povedenija u detej i podrostkov (Lvov, 1989), 55-76.

${ }^{2}$ G.G. BOCHKARJOVA, "Psihologicheskaja harakteristika motivacionnoj sfery podrostkov-pravonarushitelej," in: Izuchenie motivacii povedenija detej i podrostkov, ed. L.I. Bozhovich, L.V. Blagonadezhinoj (Moskva: Pedagogika, 1972), 259-350.

${ }^{3}$ L.M. RUDENKO, "Osoblyvosti ahresyvnoyi povedinky rozumovo vidstalyx ditej: monohrafiya” (Kyiv: Vyd-vo NPU imeni M.P. Drahomanova, 2013), 323.

${ }^{4}$ A.A. Bodalev, "Lichnost' i obshhenie" (Moskva, 1983), 284.
} 
U. Bronfenbrenner, V. Satir, L. Smith). They change under the influence of external and internal factors (V. Druzhinin, V. Kagan, O. Karabanova, I. Kon, S. Michalska, N. Poisoeva, V. Polishchuk, V. Semichenko, G. Filipov), clearly regulated by the styles of education and the rules governing the types of relationships in the family ${ }^{5}$ V. Garbuzov, O. Zharov, V. Minirov, A. Rean, G. Stepanova, D. Baumri). As the closest social environment of a child, the family satisfies their needs for kindness, cooperation, and respect; in mutual understanding and empathy (M. Ainsworth, J. Bowlby, E. Erikson, A. Freud, M. Klein, M. Mahler, D. Winnicott). Educators and psychologists (V. Druzhinin, M. Semago, A. Spivakovskaya, V. Stolin) also mention the important role of the family in the child's development. According to the teachers, the family has a priority in the education of the social and emotional culture of the child, which imitates the behavior of loved ones, adopts their manners, borrows in them a way of evaluating people, events, things, assimilates the moral norms that regulate the behavior of people in society. ${ }^{6}$ According to Bowen's family systems theory, the family is a dynamic entity with individual characteristics and needs, and is composed of people who have their own individual characteristics and are interconnected. Family system theorists argue that understanding child functioning requires understanding family dynamics (L. Smith), the quality of which affects children's functioning, and vice versa (P. Cowan, C. Cowan, D. Cohn, J. Pearson). In addition, it is assumed that different family relationships affect one another (U. Bronfenbrenner). ${ }^{7}$ The organization of effective interaction between parents and children is an important factor that hinders the formation of aggressive behavior in children with intellectual disabilities. Disruption of interaction provokes in them the appearance of anxiety, fear, feelings of insecurity, etc., which in turn affects the level of aggression. What the child receives in the family, it stores throughout life. The importance of the family as an institution of education is due to the fact that the child is in it for a considerable part of the time, and by the duration of its influence on the personality, none of the institutions of education can be compared with the family. ${ }^{8}$

5 V.I. GARBUZOv, Prakticheskaja psihoterapija, ili kak vernut' rebenku i podrostku uverennost'v sebe, istinnoe dostoinstvo i zdorov'e (Sankt-Peterburg: AO «Sfera», 1994), 160.

${ }^{6} \mathrm{M}$. СНАо, "Family interaction relationship types and differences in parent-child interactions," Social Behavior \& Personality: an International Journal (2011), 39, 7: 897-914.

${ }^{7}$ U. BRonfenBrenner, "Ecological models of human development," Readings Dev. Child. (1994), 3: 37-43.

${ }^{8}$ H.M. Andreeva, Socyal'naya psyxolohyya (Moskva: Aspekt Press, 1996), 479. 
The development of both positive and negative traits directly depends on the style of parental education (equally of parental and maternal), the nature and amount of disciplinary penalties and fines. Parenting style and behavior is a relative resilience of the adult's goals, actions, and reactions aimed at shaping the child's personality.

Children with intellectual disabilities may be included in the risk group of children with the likely occurrence of impaired behavioral responses. ${ }^{9}$ In this case, the positive or negative factors of the microenvironment become of great importance. A large number of children with intellectual disabilities are in problem families. According to G. Aunapuu, family disadvantages, defects in family education, are considered, on the one hand, as conditions conducive to deformed personality development, and on the other hand, such a state of interpersonal relations in the family when social functions are broken or excluded, aimed at compensation of the primary defect of the child, to his social, labor, household adaptation. ${ }^{10}$

Studies of the social situation of the development of children and adolescents confirm the existence of predominantly negative characteristics of the social, cultural, educational and professional status of families in which children with intellectual disabilities are raised, which may be a source of influence for children who conflict with social norms. ${ }^{11}$ Unfavorable conditions in the families of children with intellectual disabilities, lack of education, disability of parents in matters proper education, demonstration of aggressive behavior in the family and ensuring its support also cause aggressive tendencies in the behavior of children with intellectual disabilities. ${ }^{12}$ G. Zapryagayev identified the main forms of improper education in the family that contribute to the emergence of difficulties in the behavior of adolescents with intellectual disabilities: neglect, hyper caring, the presence in the family and the immediate environment of persons who lead an immoral lifestyle, immoral behavior, with whom the child constantly communicates with. ${ }^{13}$

\footnotetext{
${ }^{9}$ E.S. IVANOV, "Biologicheskie $\mathrm{i}$ social'nye faktory $\mathrm{v}$ formirovanii narushenij povedenija u uchenikov vspomogatel'nyh shkol," in: Biologicheskie $i$ social'nye faktory v formirovanii narushenij povedenija u detej i podrostkov: mezhvuz. sb. nauch. trudov (Lvov, 1989), 22-25.

${ }^{10}$ T. AUNAPUU, "Trudnovospituemost': nekotorye prichiny vozniknovenija i puti profilaktiki," in: Voprosy special'noj psihologii i didaktiki. Vyp. 826: Trudy po defektologii (Tartu, 1988), 29-35.

${ }^{11}$ I.A. KorobejNIKOv, Narushenija razvitija i social'naja adaptacija (Moskva, 2002), 23-60.

${ }^{12}$ M. Del Rosario, K. Gillespie Lynch, S. Johnson, M. Sigman, T. Hutman, "Parentrepor ted temperament trajectories among infant siblings of children with autism," Journal Autism Dev Disord Osborne LA (2014), 44: 381-93.

${ }^{13}$ G.G. ZAPRJAGAev, Psihologicheskaja harakteristika umstvenno otstalyh podrostkov s trudnostjami povedenija: dis. ... kand. psihol. nauk, (Moskva, 1986): 20-93.
} 
Cause of aggressive behavior in children, according to Summing \& Davies, 1994, Grych \& Fincham may be conflicts in family relationships between parents; between parents and children (Herrera \& Dunn, 1997); between siblings (Patterson).

The conditions of family education have a great influence on the formation of aggressive behaviors of the child. ${ }^{14}$ Most children with an asocial type of behavior are children from families with unstable types of education, with a peculiar affinity for these families to the emotional world of children and their interests, the opposite of requirements, the cruelty of punishment, and sometimes the complete absence of prohibitions and restrictions on the part of parents.

The family must adapt to the child's growing independence as she prepares for her own life. How well this parental adjustment and almost adult child's success occurs depends more on the style of parental behavior and family dynamics. ${ }^{15}$

In psychological studies of the family much attention is paid to analyzing conflicts and finding out the causes that cause them. ${ }^{16}$

Communicating with aggressive children is a particular problem that requires some parenting skills. ${ }^{17}$ As a rule, parents do not take into account the features of an aggressive child who has: poorly developed control over their emotions; poor awareness of their feelings and those of others; low level of empathy; they perceive the communication situation wary and to some extent exaggerate its threat, that is, from the outset they are set on mutual struggle.

As mentioned above, the purpose of the study was to identify unfavorable conditions of family education as one of the factors that lead to the aggressive behavior of children with intellectual disabilities.

The study involved 106 families raising children with mild intellectual disabilities, including 58 complete, 48 incomplete, and 76 families with moderate disorders, including 26 complete and 50 incomplete.

\footnotetext{
${ }^{14}$ M. MiD, Ku'tura i mir detstva, ed. I.S. Kon (Moskva: Nauka, 1988), 178.

${ }^{15}$ S. KeIM, A. KLÄrner, L. BERnARDI, "The strength and family formation: Which personal relationships are influential," Personal Relationships (2013), 20, 3: 462-478.

${ }^{16}$ M. EINAV, "Perceptions About Parents' Relationship and Parenting Quality, Attachment Styles, and Young Adults' Intimate Expectations: A Cluster Analytic Approach," Journal of Psychology (2014), 148, 4: 413-434.

17 A.E. LichKo, "Psihopatii i akcentuacii haraktera u podrostkov" in: Psihologija individual'nyh razlichij, ed. Ju.B. Gippenrejter, V.Ja. Romanova (Moskva: Izd-vo MGU, 1982), 288-318.
} 
Study methods. Features of family eduaction and attitudes to the child were revealed by the method of analysis of family education (AFE), developed by E. Eydemiller and V. Yustitsky. On the basis of the analysis of the results of this technique, the type (parent-child relations regarding their structural and role disorders) was determined: hyperprotection, hypoprotection, emotional alienation, cruel treatment of the child, education in conditions of increased moral responsibility. These types of family behavior lead to behavioral disorders and personality development abnormalities.

Investigating the family specifics relationships as one of the conditions that influence the formation of aggressive behavior in children with mild and moderate intellectual disabilities, we used the projective techniques "Family kinetic drawing" and "Three trees." When applying the Three Trees method, children were not asked to compare trees with a family member as intended by the method, and the question was, "Which family would you give this tree to?"

\section{STUDY RESULTS AND THEIR ANALYSIS}

Children's drawings were studied by qualitative and quantitative analysis. The quantitative analysis of the results used a quantitative assessment system, which identified five symptom complexes, specifically: favorable family situation; anxiety; family conflict; feelings of inferiority; hostile relationships in the family.

Qualitative analysis of children's drawings was aimed at diagnosing the child's sense of psychological comfort in the family, the perception of integrativeness, interrelation, family integrity and possible manifestations of aggressive behavior.

The study found that the most emotionally close person for children with intellectual disabilities is the mother $(37.3 \%$ of pre-schoolers, $34.1 \%$ of primary school age and $28.6 \%$ of adolescents). Of particular interest for the study are those drawings in which the child does not draw himself or instead of the family draws only himself. In both cases, the researchers do not include themselves in the family, indicating that there is no sense of community. The absence of the "I" figure is more characteristic of children who feel rejected and rejected in the family. According to the study, $4.8 \%$ of preschool children, $7 \%$ of primary school children and $9.1 \%$ of adolescents did not portray themselves as family, indicating that the child does not feel part of it and does not accept the family as a whole structure. $6.3 \%$ of pre- 
schoolers, $8.5 \%$ of younger school children and $11.3 \%$ of teenagers experience family rejection and rejection.

The qualitative analysis of the drawings of the subjects with mild and moderate intellectual disabilities also revealed that $42.4 \%$ of preschool children, $34.2 \%$ of younger students and only $28.1 \%$ of teenagers reflect family consolidation. Thus, according to the study, children with intellectual disabilities with age reduce the sense of psychological well-being, which is directly related to the family, the perception of its integrative and inclusion in the family.

Feeling disjointed with family members is characteristic of $58.1 \%$ of preschool children, $66.4 \%$ of younger school children and $72.7 \%$ of adolescents, which in turn may indicate a low level of emotional connection. Among this group of examinees there is a considerable part of children, whose family situation and perception by her child require considerable attention from the psychologist. In particular, $13.2 \%$ of preschoolers, $16.4 \%$ of younger students and $17.1 \%$ of teens in the picture depicted themselves as separate from other family members, indicating a sense of alienation experienced by the child in the family. $13.9 \%$ of preschool children, $15.4 \%$ of younger students and $14.4 \%$ of adolescents were separated from other parents by their parents; $4.1 \%$ of preschoolers, $6.9 \%$ of younger schoolchildren and $7.3 \%$ of teenagers drew a single mom; $7.5 \%$ of preschoolers, $9.7 \%$ of young children and $11.4 \%$ of teenagers in their drawings individually depicted other family members (grandparents, brother, sister). In our view, it is also interesting that in $5.3 \%$ of drawings of preschool children, $8.5 \%$ of younger school children and $7.7 \%$ of adolescents, the subjects depicted themselves with their mother, separating other family members. The results of the qualitative analysis have led to the following conclusion: a significant proportion of children with mild and moderate intellectual disabilities experience the feeling of being separated from family members, while feeling alienated from their relatives and rejected by adults. At the same time, some children are negatively treated by one adult or another in the family.

$17.6 \%$ of pre-school children, $19.6 \%$ of younger school-age respondents and $21.7 \%$ of adolescents are prone to exhibit verbal aggression.

It should be noted that a large part of those studied in their drawings reflect the hostile attitude of a family member to themselves. Thus, $11.6 \%$ of adolescent respondents, $6.1 \%$ of younger students and $3.4 \%$ of preschool children have a sense of hostility towards their child. Mothers' hostility reflects $7.6 \%$ of teens, $5.7 \%$ of younger students and $2 \%$ of preschoolers. Hos- 
tility from other family members (grandparents, siblings) is felt by $8.9 \%$ of adolescents, $6.1 \%$ of younger schoolchildren and $3.4 \%$ of preschoolers. Due to the fact that young children of preschool and preschool age are addicted to others. Feeling hostile to the child's immediate surroundings can be the cause of the child's aggressive behavior.

The cohesion of the family, which is depicted in the drawings of children, are indicators of psychological well-being, perception of the integrative nature of the family, inclusion of itself in its composition. This figure is present in the figures of $21.5 \%$ of the studied preschool age, $18.5 \%$-younger school and $13.1 \%$ - adolescent.

In contrast, $19.1 \%$ of adolescent children, $17 \%$ of younger students, and $11.7 \%$ of preschoolers found a low level of emotional connection.

Therefore, from our point of view, significant factors that influence the development of a child with intellectual disabilities in the family are: the perception of the family situation as favorable; family conflict; hostile relationships in the family; the child's anxiety about the family; feelings of inferiority; emotional closeness to the mother; emotional intimacy with the father; emotional closeness with other family members; non-integrative family; rejection and rejection of the child in the family; lack of sense of community; dissatisfaction with the psychological needs of the child in the family; family cohesion; the feeling of alienation experienced by the child in the family; feeling hostile to the mother; feeling hostile to his father; Feeling hostile to other family members low levels of emotional connection in the family.

As a result of the correlation analysis, a direct correlation was found between the high level of child aggression and rejection and rejection of the child in the family (correlation coefficient 0.46 , significance level 0.04 ), feelings of hostile attitude on the part of the mother (correlation coefficient 0.48 , significance level of 0.04 ), feelings of hostility on the part of the father (correlation coefficient of 0.51 , significance level of 0.04 ), and inverse dependence with emotional closeness with mother (correlation coefficient of -0.47 , significance level of 0.04 ) and emotional closeness to the father (co correlation coefficient -0.48, significance level 0.04).

Analyzing the results, we conclude that the high level of aggression of the child is certainly a consequence of the psychological discomfort that the child is experiencing in the family. In particular, this is due to the emotional connection between the parent and the child. The lack of emotional closeness between the child and the immediate environment causes a high level of aggression of the child. In the absence or absence of emotionally colored re- 
lationships between family members, a child with intellectual disability experiences rejection and rejection in the family, a hostile attitude on the part of both mother and father.

Direct dependence was also found between the average level of aggression of the child and the satisfaction of the child's psychological needs in the family (correlation coefficient 0.47 , significance level 0.04 ), low emotional connection in the family (correlation coefficient 0.52 , significance level 0.04 ), hostile relationships in the family (correlation coefficient 0.49 , significance level 0.04 ), anxiety experienced by the child against the family (correlation coefficient 0.50 , significance level 0.04 ). Inverse dependence was established with family conflict (correlation coefficient -0.48 , significance level 0.04). Consequently, the average level of aggression is manifested by children who feel unmet in their psychological needs, in particular, in emotional contact. They perceive the family as having a mostly hostile relationship and their members have no emotional connection. The family experiences anxiety and frustration in the family. As in the first case, the level of aggression of the child with intellectual disabilities is caused by emotional ties in the family. But children who are moderately aggressive do not perceive their own family as conflicted.

Perceiving the family situation as favorable, and the family as sufficiently organized and emotionally close to the mother and father, the child with intellectual disabilities shows a low level of aggression. It should also be noted that low levels of aggression are closely linked to the lack of a child's sense of rejection and rejection of the child in the family and the absence of hostile relations between its members. The described features of the manifestation of the child's aggression were established on the basis of a correlation analysis, in the process of which a direct correlation between the low level of the child's aggression and emotional closeness with the mother was established; (correlation coefficient 0.53, significance level 0.05), emotional closeness with father (correlation coefficient 0.47 , significance level 0.04 ), perceived family situation as favorable (correlation coefficient 0.48 , significance level 0.04 ), family cohesion (correlation coefficient 0.49 , significance level 0.04 ). Inverse dependence was established with rejection and rejection of the child in the family (correlation coefficient -0.46 , significance level 0.04 ) and hostile relationships in the family (correlation coefficient -0.47 , significance level 0.04). 


\section{CONCLUSION}

The results of the study showed that:

- the perception of the family situation as favorable is most pronounced in the drawings of preschool children, in the younger school age respondents the perception of the family situation as favorable in comparison with preschool children decreases by $8.5 \%$, while in adolescents by $11.4 \%$;

- Conflict and hostile relationships in the family are most pronounced in adolescent drawings and are least evident in preschool children;

- anxiety about family relationships and feelings of inferiority related to family are most evident in drawings of young school children.

Consequently, perceptions of the family situation as unfavorable, conflict-ridden in children with intellectual disabilities increase with age, reaching their highest levels by adolescence. Let us also note that in children of preschool age, despite the most favorable perception of the family situation, the symptoms of anxiety about family relationships are quite expressed in the drawings. Thus, we argue that the negative perception of a child with impaired intellectual development of the family situation, the lack of emotional ties between family members, the feeling of rejection and rejection of the child by adult family members causes not only the manifestation of aggression, but also the formation of aggressive behavior patterns.

\section{BIBLIOGRAPHY}

АндРеEвA, Г.М. Социальная психология. Москва: Аспект Пресс, 1996. [ANDREeVA, H.M. Socyal'naya psyxolohyya. Moskva: Aspekt Press, 1996].

Аунапуу, Т. “Трудновоспитуемость: некоторые причины возникновения и пути профилактики." In: Вопросы специальной психологии и дидактики. Вып. 826: Труды по дефектологии, 29-35. Тарту, 1988. [AUNAPUU, T. "Trudnovospituemost': nekotorye prichiny vozniknovenija i puti profilaktiki." In: Voprosy special'noj psihologii i didaktiki. Vyp. 826: Trudy po defektologii, 29-35. Tartu, 1988.].

БодАЛЕВ, А.А. Личность и общение. Москва: Международная педагог. академия, 1983. [Bodalev, A.A. Lichnost' i obshhenie. Moskva: Mezhdunarodnaia pedagog. akademiia, 1983].

БочкАРЁВА, Г.Г. “Психологическая характеристика мотивационной сферы подростков-правонарушителей.” In: Изучение мотивации поведения детей и подростков, 259-350. Под ред. Л.И. Божович, Л.В. Благонадежиной. Москва: Педагогика, 1972. [BochKARJovA, G.G. "Psihologicheskaja harakteristika motivacionnoj sfery podrostkov-pravonarushitelej." In: Izuchenie motivacii povedenija detej i podrostkov. Ed. L.I. Bozhovich, L.V. Blagonadezhina, 259350. Moskva: Pedagogika, 1972]. 
Bronfenbrenner, U. "Ecological models of human development." Readings Dev. Child. (1994), 3: $37-43$.

CHAO, M. "Family interaction relationship types and differences in parent-child interactions." Social Behavior \& Personality: an International Journal (2011), 39, 7: 897-914.

Del Rosario, M., Gillespie Lynch, K., Johnson, S., Sigman, M., Hutman, T. "Parentrepor ted temperament trajectories among infant siblings of children with autism." Journal Autism Dev Disord Osborne LA (2014), 44: 381-93.

EInAV, M. "Perceptions About Parents' Relationship and Parenting Quality, Attachment Styles, and Young Adults' Intimate Expectations: A Cluster Analytic Approach." Journal of Psychology (2014), 148, 4: 413-434.

ГАРБузов, В.И. Практическая психотерапия, или как вернуть ребенку и подростку уверенность в себе, истинное достоинство и здоровье. Санкт-Петербург: АО «Сфера», 1994. [GARBUZOV, V.I. Prakticheskaja psihoterapija, ili kak vernut' rebenku i podrostku uverennost' v sebe, istinnoe dostoinstvo i zdorov'e. Sankt-Peterburg: AO «Sfera», 1994].

ИвАнов, Е.С. “Биологические и социальные факторы в формировании нарушений поведения у учеников вспомогательных школ.” In: Биологические и соииальные факторы в формировании нарушений поведения у детей и подростков: межвуз. сб. науч. трудов, 22-25. Львов, 1989. С. [IvANOv, E.S. "Biologicheskie i social'nye faktory v formirovanii narushenij povedenija u uchenikov vspomogatel'nyh shkol." In: Biologicheskie $i$ social'nye faktory $v$ formirovanii narushenij povedenija u detej i podrostkov: mezhvuz. sb. nauch. trudov, 22-25. Lvov, 1989].

KeIm, S., Klärner, A., Bernardi, L. "The Strength And Family Formation: Which Personal relationships are influential." Personal Relationships (2013), 20, 3: 462-478.

КОРОБЕйникОВ, И. А. Нарушения развития и сочиальная адаптация. Москва: ПЕР СЭ, 2002. [KorobejNIKov, I.A. Narushenija razvitija i social'naja adaptacija. Moskva: PER SE, 2002].

Личко, А.Е. “Психопатии и акцентуации характера у подростков.” In: Психология индивидуальных различий. Под ред. Ю.Б. Гиппенрейтера, В.Я. Романовой, 288-318. Москва: Изд-во МГУ, 1982. [LıснкО, А.Е. "Psihopatii i akcentuacii haraktera u podrostkov." In: Psihologija individual'nyh razlichij. Ed. Ju.B. Gippenrejter, V.Ja. Romanova, 288-318. Moskva: Izd-vo MGU, 1982].

Мид, М. Культура и мир детства. Сост. И.С. Кон. Москва: Наука, 1988. [MID, М. Kul'tura i mir detstva. Ed. I.S. Kon. Moskva: Nauka, 1988].

ПопПЕ, Г.К. “Нарушения поведения у олигофренов.” In: Биологические и социальные факторы нарушений поведения у детей и подростков, 55-76. Львов, 1989. [РОРРЕ, G.K. "Narushenija povedenija u oligofrenov." In: Biologicheskie $i$ social'nye faktory narushenij povedenija u detej i podrostkov, 55-76. Lvov, 1989].

Руденко, Л.М. Особливості агресивної поведінки розумово відсталих дітей: монографія. Київ: Вид-во НПУ імені М.П. Драгоманова, 2013. [RUDENKO, L.M. Osoblyvosti ahresyvnoyi povedinky rozumovo vidstalyx ditej: monohrafiya. Kyiv: Vyd-vo NPU imeni M.P. Drahomanova, 2013].

ЗАПРЯГАЕВ, Г.Г. Психологическая характеристика умственно отсталых подростков с трудностями поведения: дис. ... канд. психол. наук. Moskva, 1986. [ZAPRJAGAev, G.G. Psihologicheskaja harakteristika umstvenno otstalyh podrostkov s trudnostjami povedenija: dis. ... kand. psihol. Nauk. Moskva, 1986]. 


\section{RODZINA JAKO DETERMINANT ZACHOWANIA AGRESYWNEGO U DZIECI Z ZABURZENIAMI INTELEKTUALNYMI}

\section{STRESZCZENIE}

Artykuł poświęcony jest badaniu przyczyn zachowań agresywnych u dzieci z niepełnosprawnością intelektualną w różnym wieku. Zauważono, że zaburzenia zachowania u dzieci z niepełnosprawnością intelektualną występują w 25\%-84\% przypadków, a rozwój cech zarówno pozytywnych, jak i negatywnych zależy bezpośrednio od wychowania w rodzinie. Badanie sytuacji społecznej rozwoju dzieci i młodzieży niepełnosprawnej intelektualnie potwierdziło obecność przeważnie negatywnych cech statusu społecznego, kulturowego, edukacyjnego i zawodowego rodzin, w których wychowuje się dzieci niepełnosprawne intelektualnie, co może być źródłem wpływu sprzecznego z normami społecznymi. Niekorzystne warunki w rodzinach dzieci z niepełnosprawnością intelektualną, brak wychowania, niekompetencja rodziców w sprawach wychowania, przejawy agresywnego zachowania w rodzinie i niezapewnienie jej wsparcia powodują również tendencję do zachowań agresywnych tej kategorii dzieci.

Stwierdzono, że postrzeganie sytuacji rodzinnej jako niekorzystnej, konfliktowej u dzieci $\mathrm{z}$ niepełnosprawnością intelektualną wzrasta $\mathrm{z}$ wiekiem, osiągając najwyższy poziom przed okresem dojrzewania. Udowodniono, że negatywne postrzeganie sytuacji rodzinnej przez dziecko z intelektualnym zaburzeniem, zaburzone więzi emocjonalne między członkami rodziny, poczucie nieprzyjęcia i odrzucenia dziecka przez dorosłych członków rodziny powoduje nie tylko przejawy agresji, ale także powstawanie zachowań agresywnych.

Słowa kluczowe: zachowania agresywne; rodzina; sytuacja rodzinna; dzieci niepełnosprawne intelektualnie; czynniki behawioralne. 